\title{
Some aspects of sustainable development management of business entities
}

\author{
Daria Presnyakova* and Elena Khryuchkina \\ Yelets branch of ANO VO "Russian New University", Lomonosov, 13, 399770 Yelets, Russia
}

\begin{abstract}
The article deals with the management of sustainable development of business entities. So, stability characterizes the current state of a certain economic object to the pressure of external factors. In order to increase the stability of the organization to the effects of various factors, it is necessary to improve the object itself in such areas as social, economic and financial stability. These concepts are interrelated and actively affect the current economic activity of the facility. This article discusses various approaches to determining the sustainable development of organizations at different levels of business processes. The aim of the study of management of sustainable development of business entities is to develop optimal mechanisms of economic management that ensure the current sustainability of organizations. To achieve this goal, the issues of social, economic and financial stability of organizations were considered, the main trends and results of economic decisions during the functioning of economic entities were analyzed, the degree of their resistance to market conditions was determined. The theoretical and methodological basis for the study of sustainable development management of business entities were the works of domestic and foreign scientists in various fields of economics, enterprise management, and a comprehensive analysis of the financial and economic situation. For clarity, the authors have built figures, prepared tables and analyzed the data obtained. The article draws conclusions about the role of sustainable development in the economic life of business entities.
\end{abstract}

\section{Introduction}

An important condition for the long-term development of business entities is management and sustainability support. The term "sustainable development" was introduced into widespread use by the International Commission on Environment and Development (Bruntland Commission) in 1987. Sustainable development is defined as such development that meets the needs of the present, but does not compromise the ability of future generations to meet their own needs. [1] The sustainability of the development of an economic object is pressured by many significant factors, for example: the current position of the enterprise in the product market; production and output of main products, supply and demand trends; economic potential in long-term cooperation; profitability of business processes; efficiency of financial transactions, etc.

\footnotetext{
${ }^{*}$ Corresponding author: gadavl@list.ru
} 
For example, for economic entities that carry out economic activities in a particular region, it is important to have a sustainable development strategy, taking into account the long-term development of a particular region. In this case, sustainable social, economic and financial development of this facility will be achieved subject to compliance with the developed and adopted measures for the sustainability of territories, industries and organizations.

Thus, ensuring the socio-economic sustainability of economic facilities will allow maintaining the competitive potential, while ensuring the achievement of indicators for social and environmental stability. According to the authors, ensuring socio-economic sustainability is associated with the ability of organizations to maintain a sufficient degree of developed economic goals in the context of the development of a competitive market. In this case, the main characteristics of sustainable development can be considered the reliability of the economic structure of regional systems, the adaptability and elasticity of regional reproduction, when there are natural variations in demand, and when there are no sharp fluctuations in socio-economic processes. [5]

The financial stability of organizations is a reflection of the excess of current income over expenditures, which makes it possible to ensure free maneuvering of funds through their effective use over a certain period. Also, such a strategy ensures a smooth process of production and sale of finished products. The authors believe that the financial stability of an economic entity is such a state of material and financial resources that allows the redistribution and use of available resources to ensure stable development. Such a sustainability management strategy is often based on the methodology for the growth of profits and capital while maintaining the solvency and creditworthiness of economic entities under conditions of an acceptable level of risk. In this case, financial and socioeconomic stability will be formed in the process of production and economic activity, and will be the main element of the overall stability of the organization. In this case, an individual organization can be considered not only as a participant in market relations, but also as a special element of the social, economic, natural and financial environment. [6]

In the modern period, the concept of "sustainability" is considered in different categories of knowledge (Fig. 1)

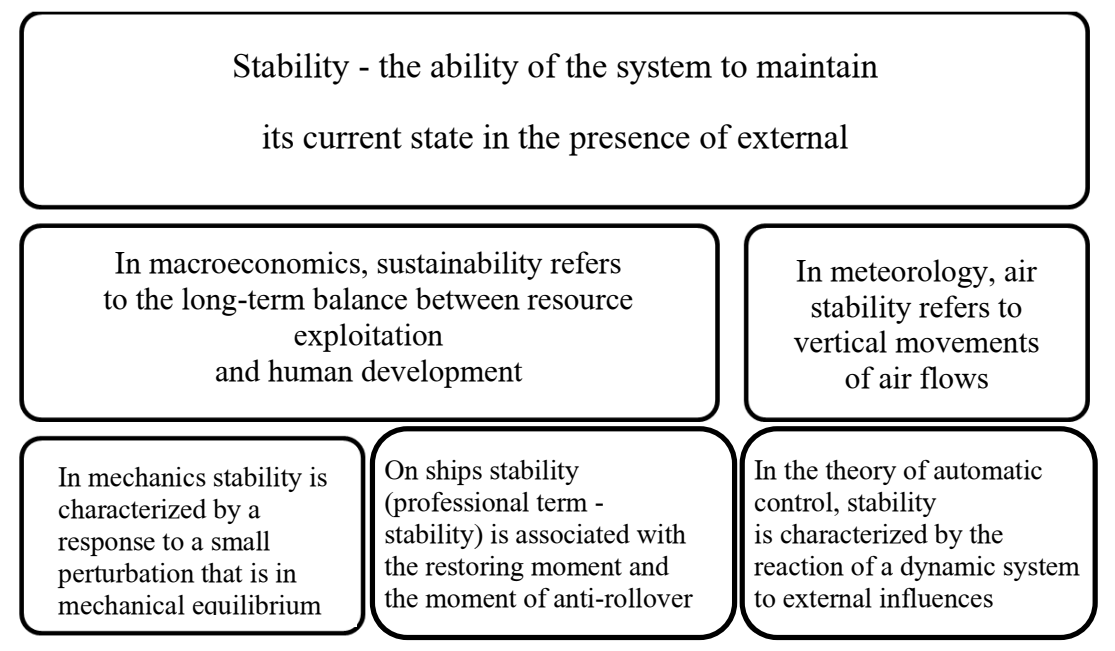

Fig. 1. The concept of the category "sustainability".

So, the schematically presented concept of the category "sustainability" is a relative category that can be assessed in comparison with other objects. In addition, stability 
characterizes the state of an economic object in relation to external influences. In this case, the more stable is the state of the economic object, which, with equal strength external influences and internal negative factors, is subject to smaller changes and deviations from the established position. In this case, the economic growth and development of organizations is ensured. [6]

So, according to I. Schumpeter, economic growth is an increase in production and consumption of the same goods and services over time, and economic development is the emergence of something new, previously unknown, in other words, innovation. [3]

An important condition for determining a reliable level of stability of economic objects to external influences are the internal properties of the object itself. Thus, the modern experience of organizations that succeed in a tough competitive environment convinces us that to ensure sustainable development, it is necessary to quickly make competent management decisions by managers, which allows them to respond in a timely manner to changes in market conditions. It also makes it possible to improve the level of production efficiency and competitiveness of finished products, increase investment activity, maintain liquidity and financial stability in the long term. According to the authors, sustainability is an external form or an external manifestation of the internal economic structure, and a stable foundation for sustainability should be laid within the organization itself. In order to increase the organization's resistance to the effects of various factors, it is necessary to constantly improve the object from the inside, using innovative factors of self-development. Therefore, as a result, it is possible to formulate a general concept of sustainable development of business entities. Sustainable development is the ability of organizations to maintain a set level of achievement of economic goals in the context of dynamic development of the business environment.

\section{Materials and Methods}

The development of a modern economic system, which includes the activities of business entities, is the interaction of different elements of opposite sides and current trends. Each economic change is the result of practical experience and theoretical research, which makes it possible to establish possible changes in advance, and then substantiate different forms of stability, key features, signs and borderline states. It should be noted that the sustainable development of the country, regions and industries is achievable by ensuring the strategy of economic sustainability for individual elements, since the sustainable development of an individual organization allows the entire economic system to retain its potential and, in the future, ensure the growth of production and sales of competitive products.

The problem of ensuring sustainable development of organizations is of particular importance when organizing a business, since it is necessary to effectively use modern methods of adaptation to changes in the external environment. This allows you to quickly carry out the process of diversification of production, make changes to the nomenclature of finished products, expand market relations, as well as optimize the structure of fixed assets, change the organizational forms of enterprises, etc. In the modern period, small business entities may not have good opportunities to reduce risks, therefore, changes in some criteria of the external environment may have a negative impact on economic activity. For example, you can consider the organizational and economic sustainability of small business organizations, taking into account the following aspects (Fig. 2,3). The first aspect is to identify ways of sustainable development of production of enterprises in the market conditions of management. 
The first aspect is to identify ways of developing the production process in the market conditions of management. It includes:

-diversification of production activities,

-construction of business processes,

- improvement of the system of interaction with external organizations,

- improvement of the order and procedures that are used in the interaction of

elements of the organization's structure,

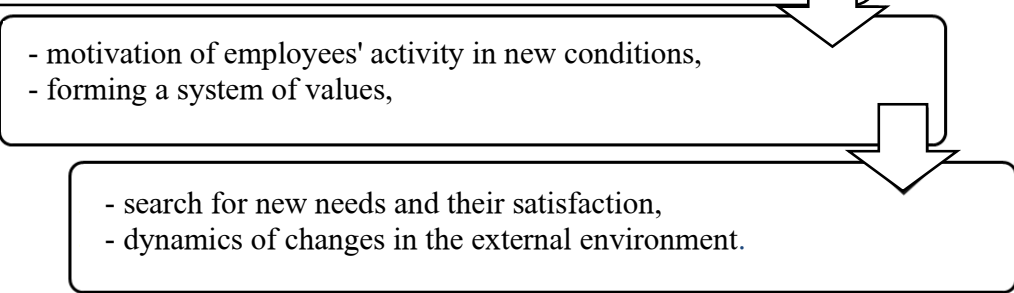

Fig. 2. Identification of ways of sustainable development of production of enterprises in the market conditions of management.

The second aspect consists in identifying specific elements that contain quantitative and qualitative organizational changes taking place in the management strategy. At the same time, special moments influencing organizational changes can be represented as follows (Fig. 3)

In general, sustainable development of entities is achieved in the process of strategic management of important elements of economic development, for example: investment activity, competitiveness, production technology, financial resources, etc. This allows for timely diversification of production while maintaining a high level of competitiveness of finished products, while constantly ensuring organizational and economic flexibility and integrity of the economic process of the entire economic complex.

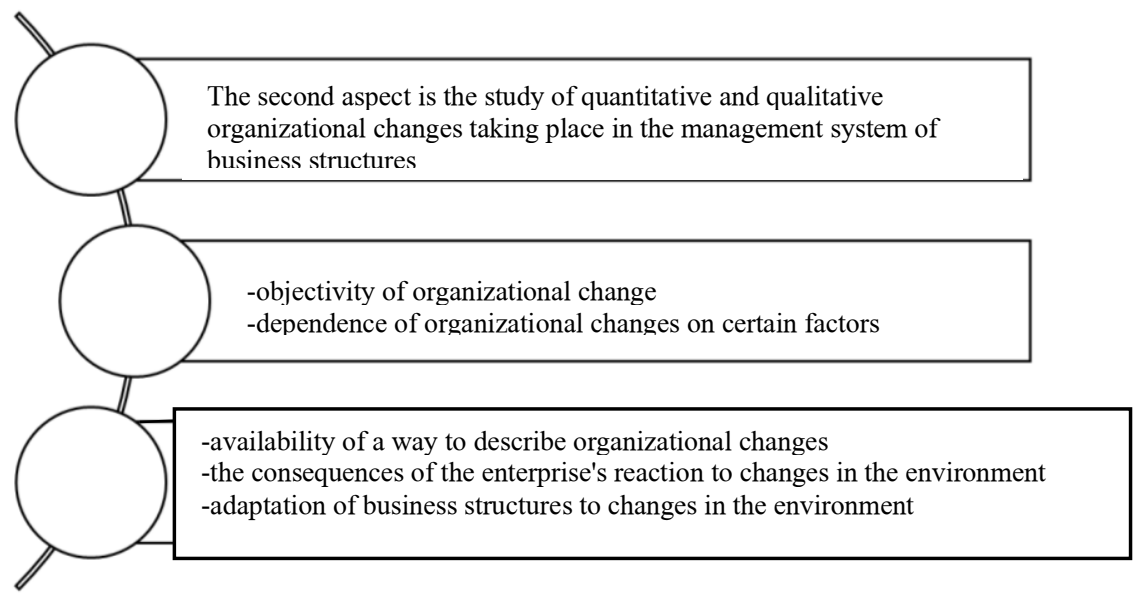

Fig. 3. Determination of quantitative and qualitative organizational changes taking place in the enterprise management system 
For example, to ensure stability and self-regulation in a changing external environment, the regional economic complex must have a certain development potential according to the most significant parameters, to the formation of which a systematic approach must be applied. [5]

Thus, the authors believe that the economic development of an enterprise is sufficiently stable if important conditions can be provided, for example: production is aimed at fulfilling the tasks of long-term development; the production process is consistent with the dynamics of product markets and major consumers; there is a high level of financial independence and autonomy; a universal control system is used, which is necessary for self-organization and development. Ensuring effective management of sustainable development of organizations in the modern period is becoming a key task, which allows us to restrain the pressure of external and internal negative factors.

\section{Results and Discussion}

The study of the essence of sustainable development of economic entities showed a lack of consensus on the definition of this category, since in modern economic literature one can separately find definitions of organizational-economic, financial or financial-economic stability. Therefore, it is necessary to identify the basic characteristics of managing the sustainable development of economic entities, which will allow to establish the levels of economic dynamics, to identify the circumstances that form the economic space, and then it will be possible to adequately assess the consequences of management decisions taken.

So, the level of development of the financial stability of the organization can be determined based on the analysis of the balance sheet of assets and liabilities and reports on financial results for a specified period. In this case, the current assessment of the financial condition of the organization can be based on key indicators: liquidity; financial stability; profitability and business activity. Financial stability characterizes the overall stability of the organization, and its ability to meet its obligations. For example, Fedotova M.A. believes that a special form of stability is resistance stability. This is a state of equilibrium when the enterprise is operating fairly stable, despite the pressure of negative factors. Therefore, an object is considered stable if, with equal external influences and internal negative factors, the current economic work is subject to the least deviations. [4]

In the modern economic practice of organizations, some criteria of financial stability are considered, namely: financial stability; provision with own circulating assets; maneuverability of own circulating assets. This allows you to determine the current financial position and the degree of financial independence. It also becomes possible to attract additional material and monetary funds for the development of production. The transition to a competitive market has changed the economic situation, enterprises have become active participants in market relations. Business decisions related to the production and sale of finished products, establishing contacts with counterparties, purchasing fixed assets and tangible assets were transferred to the competence of the enterprise. In this case, the responsibility increases, since the enterprise is responsible for the attracted resources, and financial risk may arise with an increase in the volume of short-term liabilities. Therefore, at this stage, there have been serious changes in the structure of economic entities by type of economic activity (Table 1). 
Table 1. The share of unprofitable organizations and the amount of loss by type of economic activity.

\begin{tabular}{|l|l|l|l|l|l|l|}
\hline \multirow{2}{*}{$\begin{array}{l}\text { Kind of } \\
\text { activity }\end{array}$} & \multicolumn{2}{|c|}{2017 year } & \multicolumn{2}{c|}{2018 year } & \multicolumn{2}{c|}{ 2019 year } \\
\cline { 2 - 7 } & $\begin{array}{l}\text { Share of } \\
\text { unprofitable } \\
\text { organizations, }\end{array}$ & $\begin{array}{l}\text { Loss amount, } \\
\text { million } \\
\text { rubles }\end{array}$ & $\begin{array}{l}\text { Share of } \\
\text { unprofitable } \\
\text { organizations, } \\
\%\end{array}$ & $\begin{array}{l}\text { Loss } \\
\text { amount, } \\
\text { million } \\
\text { rubles }\end{array}$ & $\begin{array}{l}\text { Share of } \\
\text { unprofitable } \\
\text { organizations } \\
\%\end{array}$ & $\begin{array}{l}\text { Loss } \\
\text { amount, } \\
\text { million } \\
\text { rubles }\end{array}$ \\
\hline $\begin{array}{l}\text { Total } \\
\text { including } \\
\text { by type of } \\
\text { economic } \\
\text { activity }\end{array}$ & 31,9 & 5042249 & 33,1 & 5932383 & 26,5 & 1937840 \\
\hline
\end{tabular}

${ }^{*}$ Russia in numbers. 2020: Brief Statistical Collection of Rosstat.M.550. (2020), Russia in Figures. 2019: Brief Statistical Collection of Rosstat.M.549. (2019) [8, 9]

From the data of this table, it can be seen that the share of unprofitable organizations compared to 2017 in 2018 amounted to $33.1 \%$, the amount of loss was 5932383 million rubles, and in $2019-26.5 \%$ and 1937840 million rubles. respectively. Thus, the unprofitable financial condition of enterprises is the result of ineffective mechanisms for regulating economic relations, and the sustainable development of enterprises depends to a greater extent on the impact of internal and external factors of the current competitive environment. The authors believe that the insufficient elaboration of economic mechanisms for ensuring sustainable development of business entities dictates the need for further research on theoretical and methodological issues of solving this problem, especially in conditions of fierce competition. For example, the financial and economic stability of an organization arises if it is possible to determine the equilibrium state in a timely manner, i.e. to establish an optimal ratio of own and borrowed funds, which will allow to painlessly cover current monetary obligations. The calculated position of the equilibrium point also allows us to establish the most favorable limit of financial and economic stability and the zone of tension and risk.

In order to more accurately establish the level of sustainable development of a business object, it is necessary to determine key indicators for the use of valuable assets, financial resources and fixed capital. At the same time, an important place is occupied by the analysis of the structure of property, the dynamics of assets and liabilities, which makes it possible to determine the maximum volumes and urgency of their use. Sustainable development of economic objects always depends on the current financial situation, therefore it is necessary to analyze the ratio between assets and own funds. For this, it is necessary to use a set of coefficients that make it possible to assess the current state of material and financial resources, their dynamics and the degree of production security. According to the data obtained, one can judge the degree of sustainable development, the sufficiency of material and financial support for economic life, and a timely analysis of financial ratios allows you to constantly regulate current economic processes, and then take prompt measures to improve the structure of valuable property and monetary funds.

Despite the universal methodology for analyzing financial results, situations may arise when the data obtained is not enough to determine the level of sustainable development of the organization. In this case, the economic activity of the organization should be carried out taking into account negative external factors, for example: economic crisis, inflation, financial instability, etc. An economic entity must be ready for changes in the external environment, especially when implementing investment projects, when it is required to attract a large amount of funds. It is also necessary to analyze commercial transactions concluded during the planning period, which makes it possible to determine in time the 
amount of necessary funds, taking into account taxation, the acquisition of patents, licenses, quotas, etc.

Thus, if, according to the results of the analysis of the financial condition, the stability of the organization is in question, then it is necessary to revise the strategy for further economic development and abandon the current production profile. This immediately forces managers of organizations to determine the current situation in the market to accurately determine the possibilities of obtaining credit resources and budget financing of promising projects.

\section{Conclusions}

Sustainable development of an economic entity is characterized by the current state of a certain object in relation to external and internal influences, as well as the presence of regulation mechanisms, thanks to which it is possible to develop or change production, technological and other economic processes, as this leads to the normalization of the ratio of supply and demand, costs and income, etc.

Management of sustainable development of business entities is understood as the ability of a certain system to adequately respond to changes in external and internal factors. According to the authors, consideration of only individual indicators of the financial condition of an organization is not enough for a comprehensive solution to increase the level of stability of an organization in today's competitive environment. In addition to the accepted financial stability, there are also price, technological, organizational, social stability, which have a different effect on the sustainable development of the enterprise. For example, when organizing a new production, the commercial risk increases, since sales and product revenue may decrease. Negative consequences can also arise with the deepening of the technological specialization of individual divisions of the enterprise. Then the problem of using some methods of managing sustainable development in a competitive economy may arise, especially under the pressure of external and internal factors. It should be noted that the basis for ensuring sustainable development is the implementation of the principles of immediate response to changes in various factors, which allows maintaining the stability of the economic environment in which economic activity is carried out. This can be achieved through an effective strategy for managing material and financial resources, fixed assets, attracted funds.

The authors propose to highlight the constituent elements of sustainable development of an economic entity, namely: financial, production, technical, commercial, organizational, innovation and social sustainability. This will allow establishing the levels of stability of the production cycle and the provision of material and financial resources. Management of sustainable development of a business entity is ensured through the stability of the organizational structure and communication links between various departments and services, which increases the efficiency of joint work on the introduction of new technologies, the release of innovative products, the performance of various works and services. [5] This allows us to take timely measures to increase the level of business activity due to the reliability of commercial ties and competitive advantages in the market.

\section{References}

1. Our common future. Report of the International Commission on Environment and Development. M. (1989).

2. R.I. Shniper, Region: economic management methods (1991).

3. J. Schumpeter. Economic development theory (1982). 
4. M.A. Fedotova. Finance. 6 (1995).

5. D.V. Presnyakova, Socio-economic phenomena and processes, 8,129 (2011).

6. D.V. Presnyakova, Bulletin of the Tambov University. Ser .: Gum. Sciences. 12, 42 (2011)

7. D.V. Presnyakova, Socio-economic phenomena and processes. 9, 138 (2011).

8. Russia in Figures. 2020: Brief Statistical Book of Rosstat.M.550. (2020)

9. Russia in Figures. 2019: Brief Statistical Book of Rosstat M.549. (2019)

10. A.M. Petrov, Russian Economic Bulletin, 2, 5 (2019)

11. V.A. Koptyuga, V.M. Matrosov, V.K. Levashova. A new paradigm for the development of Russia in the 21st century. Comprehensive study of sustainable development problems: ideas and results. Ed. 2nd. M. Academia (2000). 